\title{
Gendered Dimensions of Trade: Evidence from Arunachal Pradesh, India
}

Dr Kaushalendra Pratap Singh, ${ }^{\dagger}$ Saumya ${ }^{\hat{*}^{*}}$ and Chetna K. Rathore ${ }^{¥}$

\section{Abstract}

International trade has traditionally played an essential role in driving women-centric economic empowerment. Women's participation as owners or managers has remained consistently low over the years. In India's case, a previous study conducted by UNDP revealed that women entrepreneurs preferred engaging in informal cross-border business as it was less risky with no tax burdens and their discomfort in dealing with male customs officials (UNDP, 2016). One of the critical limitations of active business engagement is socio-economic and cultural restriction, especially at the grassroots level. The case in Arunachal Pradesh is no different, as the concept of entrepreneurship of women in this field is a relatively recent phenomenon. In Arunachal Pradesh, the market is mainly controlled by women, yet women's participation in small and medium enterprises is less in number. In this context, the current paper discusses the nature of women entrepreneurs' role in Micro, Small, and Medium Enterprises (MSMEs) and cross-border trade. It unveils the challenges faced by women entrepreneurs in Arunachal Pradesh and along with industrial and policy-related bottlenecks. The discussion is based on the primary data collected from the womenled/managed/owned MSMEs to study the gender dimensions of trade in Arunachal Pradesh. The findings of the study are that women entrepreneurship primarily gravitates around smaller sized firms, with most women-led enterprises accounting for micro-enterprises in the formal sector. Like elsewhere in Arunachal Pradesh, there remain socio-economic and cultural restrictions, especially at the grassroots level. Women lag in terms of awareness about import and export, technology, and dedicated bank accounts.

Keywords: Entrepreneurship; Gender; Trade; Arunachal Pradesh; India

\footnotetext{
${ }^{+}$Assistant Professor, Department of Social Work, Rajiv Gandhi (Central) University, Arunachal Pradesh Email: gaur.kpsingh@gmail.com

îAssistant Professor, School of Social Work, IGNOU, New Delhi, India

${ }^{*}$ Corresponding Author, Email ID: saumya@ignou.ac.in

¥ Research Associate at CUTS International, Jaipur, India, Email ID: chr@cuts.org

(C) 2021 Singh et al. This is an Open Access article distributed under the terms of the Creative Commons Attribution License (http://creativecommons.org/licenses/by/2.0), which permits unrestricted use, distribution, and reproduction in any medium, provided the original work is properly cited.
} 


\section{Introduction}

Gender Equality has been set as one of the goals to be achieved under the United Nations Sustainable Development Goals-5. This is based on the fact that women are discriminated against in most economic processes throughout the world. This discriminatory behaviour against women is inherent and has been perpetuated through social norms and customs. When women are economically empowered, there is a reduction in gender inequality, which in turn contributes to the overall development of the economy.

Women's rights and gender equality are vital to women's economic empowerment. The two concepts of gender equality and women's empowerment are closely related but quite distinct. Gender equality is about women's relative status compared to men's status, while women's empowerment bears on whether women hold the ability to exercise control and have choices/options over strategic and practical decisions. Women's empowerment is a more dynamic concept and is more challenging to measure than gender equality as it encompasses various complex dimensions, such as social structures, institutions, and norms, which can be highly context-specific.

Entrepreneurs help to remove regional disparities through setting up business in less developed and backward areas. The growth of industries and business in these areas leads to many public benefits like road transport, health, education, entertainment, etc. Setting up more industries leads to more development of backward regions and thereby promotes balanced regional development. Entrepreneurship reduces the concentration of economic power amongst the population. Through their unique offerings of new goods and services, entrepreneurs break away from tradition and indirectly support freedom by reducing dependence on obsolete systems and technologies.

The interesting interaction of entrepreneurship and economic development has vital inputs and inferences for policymakers, development institutes, business owners, change agents and charitable donors (Mohammad \& Ayah, 2019). Though India is fast evolving, it remains a patriarchal society in which women have to fight many battles in order to become successful entrepreneurs. The principle of gender equality is enshrined in the Constitution of India, which confers equal rights and opportunities to both men and women, but still, gender inequality is a significant barrier to women's entry into the business field.

Participation of women through Micro-SmallMedium Enterprises (MSME) is one of the ways to integrate women in economic activities and curb gender inequalities. Women themselves can establish a unit of their own, or they can be absorbed in others units as labourers. Different developed and developing countries' governments also endorsed the significant role of MSMEs in economic development and women empowerment.

Furthermore, trade has traditionally played an essential role in driving women-centric economic empowerment. Trade facilitation measures improve the trading environment by reducing transaction costs and thereby increasing the gains from trade. Although the use of trade facilitation measures for tackling trade bottlenecks has gained traction in recent times in South Asia, one aspect which remains largely unexplored is the importance of gender sensitivity in trade facilitation (Taneja, N., Joshi, S., Prakash, S., Bimal, S., 2018). Before going to the study's objectives, it is important to mention the 'Act East' policy, which was announced in 2014. This policy replaced the Look East Policy initiated in 1991, spearheaded by the new economic reforms of the 1990s. Focusing on culture, commerce, connectivity and capacity building through diplomatic relations with the Asia Pacific region, the Act East Policy emphasises building strategic economic cooperation between India and the Association of South-East Asian Nations (ASEAN) (Pulla et al., 2020). One of the objectives of this Act is to use North East India as a gateway to ASEAN (Pulla et 
al., 2020), signalling that the entrepreneurs could benefit from this policy as it aims at promoting economic relations with neighbouring Asia-Pacific countries. However, little is known as to what extent entrepreneurs of North East India have been benefitted from this Act. This study, too, does not probe whether women entrepreneurs of Arunachal Pradesh, the land of India's rising sun, have been benefitted from the Act East Policy. Rather, the study aims to identify the problems faced by women as entrepreneurs in relation to the current policies, infrastructure, institution and hurdle in operating trade in the domestic market and across the national boundary. The discussion is based on the primary data collected from the women-led/managed/owned MSMEs examining the gendered dimensions of trade. The study's findings suggest that in Arunachal Pradesh, women have emerged as entrepreneurs, but they went through many hurdles to start up their enterprise in terms of social, financial, and lack of proper knowledge could not generate profitable turnover. If appropriate measures are taken, they can expand their business in the domestic and international markets. However, only a few are aware of cross border trading, and only some have attempted.

As stated above, the study discusses the nature of women entrepreneurs' role in Micro, Small and Medium Enterprises (MSMEs) and crossborder trade. It unveils the challenges the women face in Arunachal Pradesh and the industrial and policy-related bottlenecks. The study is organised into seven sections. In continuation to this introductory section, the methodology adopted in the study is explained in the next section. Following this, it discusses women's empowerment and gender equality with reference to Women in Development (WID), Women and Development (WAD), and Gender and Development (GAD) approaches. This section is followed by a description of the role of women as entrepreneurs in India and Arunachal Pradesh. The following two sections detail the findings of the primary survey and key findings. Lastly, the study concludes with a recommendation based on the findings.

\section{Methodology}

The paper is based on a qualitative study using a descriptive research design. Data collection for the study was done from both primary and secondary sources. The primary data was collected through a structured interview schedule comprising of both closed and openended questions. The study was conducted in nine different districts of Arunachal Pradesh, namely, Papum-pare (the capital district), Changlang, East Siang, Longding, Lower Dibang Valley, Lower Subansiri, Namsai, Shi-Yomi, and Tawang, which covers almost all the zones (North, South, East, West and Centre) of the border state. The interview schedule was designed in English language. However, the indepth interviews were carried out by investigators who were trained to interview and translate it in the local language or Hindi language as required. In Arunachal Pradesh, Hindi is understood and spoken widely. Many of the respondents were well versed in English language as well. Data was also collected through Focused Group Discussion (FGD) with 12 women entrepreneurs from Arunachal Pradesh.

Data was collected on details of the respondents, organisational profile, domestic market access, transport and logistics, international market access, awareness about trade procedures and formalities, exception/subsidy, international market access challenges related to transport, international market access challenges related to trade logistics and standards, international market access challenges to customs and border, grievance redressal, level of digital inclusion, level of financial inclusion and social factors. In addition to this, the secondary data was collected through online articles, research reports, government websites and relevant research publications.

\section{Sampling: Size, Technique, Description}

For the study, purposive sampling was used, and the data was collected from thirty (30) respondents from nine districts of Arunachal Pradesh, as mentioned above. Women respondents who owned/led/managed MSMEs 
were purposefully chosen from the selected districts.

\section{Data Collection Process}

Data collection was done in two phases - the first one was from 26 February to 6 March 2020 during which far-away areas like Ziro and Namsai were covered, and the second phase was from 814 March 2020, during which Itanagar (Capital city) and the nearby areas were covered.

\section{Limitations of the Study}

Owing to a small sample size and non-probability sampling technique, broad generalisations could not be scientifically extracted for a larger population. However, the details of information and structured data collection tools helped us draw concrete understanding, if not long-term predictions.

\section{Ethical Considerations}

Informed consent from the respondents was taken before data collection for the purpose of this study. Respondents' self-determination in terms of any unwillingness to share information about their establishment was respected. It was also assured to the respondents that the data would be purely used for research purposes and not for drawing any extraneous benefits. In the process of data collection, no false assurance or any short or long term profit to the respondent was promised. We use pseudonyms for all the respondents.

\section{Women's Empowerment and Gender Equality: WID, WAD and GAD Approaches}

The modernisation policies have been unsuccessful in benefitting women because of how social relations and cultural factors affected the distribution of roles in the productive economy, between women and men. In order to understand the concepts of and interplay between gender and development, we need to refer to gender theorists who have proposed mainly three approaches: Women in Development (WID), Women and Development (WAD) and Gender and Development (GAD).

The WID approach advocated for integrating women into existing development projects and setting up women-only projects that addressed everyday needs (Kabeer, 1994; Tinker, 1990; Rathgeber, 1990). Boserup (1970) provided Women in Development (WID) analysis and women's roles in economic development through her comparison of different farming systems and her study of gender roles in Africa, Asia and Latin America. She showed how the modernisation process was marginalising women from the productive economy and how division of labour is socially constructed. For Boserup, unless development policy supports women in having increased access to productive labour, training and education and the productive economy in general, they will remain marginalised and subordinate.

Women's subordinate position is analysed mostly in terms of women's relation to the productive economy. She further emphasised that lack of access to productive resources or activities, in addition to the reproductive roles, are the main sources of women's subordination. In turn, this constrains their ability to make use of development opportunities. The women in Development (WID) approach emerged in the 1960s and focussed on addressing women's issues in development projects. Boserup's work provided an overview of women's role in the development process, highlighted the visibility of women's work, and emphasised women and men's contributions to economic growth.

The Women and Development (WAD) perspective came forth in the 1970 s as a criticism of WID approach. This approach was based on Feminist Marxist approaches and argued that women had been always a part of the development process. Both their contribution inside and outside the household was seen as important for the maintenance of society (Muyoyeta, nd). This perspective laid emphasis on the economic role played by women both inside and outside the home. It considers these activities essential for the survival of the family unit. It saw women as a homogeneous group, ignoring the crucial differences of class, race or ethnicity (Zwart, 1992). Rathgeber (1990) says that even though the WAD approach highlights a more critical view of women's position 
compared to WID, it misses to analyse " the relationship between patriarchy, differing modes of production, and women's subordination and oppression" (493).

In the 1980s, the model of Gender and Development (GAD) was developed by the gender advocates focussing more on relative gender analysis. This approach argued for equality in all areas, on transforming the relationships between the genders in a more egalitarian sense, in which there are significant gaps between men and women, viz. the division of labour, access to services and resources, control of resources, benefits and decisionmaking power (CQFD \& AQOCl, 2004). This approach focusing on social transformation, development and relations between men and women (Jackson and Pearson 1998) talked about how women and men manage with costs and opportunities associated with economic transformation policies and the process of globalisation. Further, it showed how differences in age, class, religion, and location influence the results (Jaquette and Staudt, 2006). It is based on socialist feminism (Rathgeber, 1990), where gender relations became the main category of analysis. This perspective took into consideration various structures and processes which in turn gave rise to disadvantaged position of women or to male superiority. This approach was critical of the assumptions of earlier two approaches of WID and WAD, where women were seen as a homogeneous group. Instead, it argued that women are differentiated by class, race, religion, and other social characteristics.

WAD and GAD approaches see women as active agents in the production and development process (Beneria, 2003; Onyejekwe, 2004). Rathgeber (1990, p.494) says:

GAD is not concerned with women per se but with the social construction of gender and the assignment of specific roles, responsibilities, and expectations to women and to men.

Participation of women in all spheres of society, involvement in politics, decision-making processes and access to power are core achievement of equality, peace, development and empowerment (Mlambo \& Kapingura, 2019). In the context of the above discussed three approaches of WID, WAD and GAD, the study looks into the nature of women entrepreneurs' role in Micro, Small and Medium Enterprises (MSMEs) and cross-border trade. It talks about the challenges faced by the women entrepreneurs in Arunachal Pradesh in relation to the current policies, infrastructure, institution and hurdles in doing trade in the domestic market and across the national boundary.

\section{Overview of Gender Parity and Women's Entrepreneurship in India and Arunachal Pradesh}

The Micro, Small, and Medium Enterprises (MSME) sector is a highly vibrant and dynamic sector of the Indian economy. The MSME sector has often been termed as an engine of growth for developing countries. This sector contributes significantly to the manufacturing output, employment and exports of the country. The MSMEs, including Khadi and village/rural enterprises, are credited with the highest employment growth rate. This sector takes less capital per unit of labour, traditional skill, local resources etc. It also plays a vital role in economic development with its effective, efficient, flexible, and innovative entrepreneurial spirit.

India's government has made special provisions for women under various sectors, such as Public Procurement Policy for Micro and Small Enterprises (MSEs). Further, under Market Development Assistance Scheme, MSMEs, Women Entrepreneurs gets reimbursement of 100 per cent of space rent and economy class airfare. However, trade policies are gender natural, and India was also among other countries to oppose gender issues getting introduced at the WTO in 2017. India argued that while it supports gender equality, gender is not a trade-related subject.

On the other hand, Arunachal Pradesh has the lowest population density of any state in India, which is 17 persons per square km (Census of India, 2011). It is one of the least studied states in India, located in the north eastern part of the 
country, and is in a transitional phase of its socioeconomic development. Polygyny is still an established practice in a few of the major tribes of the state. Women continue to take the back seat when it comes to economic and political decision making in the state. In the last two elections of the unicameral state legislature, which was held in Arunachal Pradesh during 2014 and 2019, women members could occupy only 02 (two) and 03 (three) seats respectively in Legislative Assembly comprising 60 (sixty) seats.

However, women in Arunachal Pradesh play a significant role in agriculture, looking after live stocks and collecting fuel-wood, vegetables, etc. The importance of women is reflected in the general belief among various tribes that the mother is the origin of everything. Unlike the other states in India, Arunachal Pradesh is located in rugged geographical terrain. This acts as a major challenge in setting up an enterprise. The volume of production is another major challenge for entrepreneurs as it increases the cost of transportation. If the quantity produced is less than required, then it does not fulfil the demands of domestic and cross border markets.

\begin{tabular}{|c|c|c|c|c|}
\hline S. No. & Indicators & India & Arunachal & Source \\
\hline 1. & Sex Ratio & 940 & 920 & Census 2011 \\
\hline 2. & Female Literacy Ratio & 65.46per cent & 59.57per cent & Census 2011 \\
\hline 3. & $\begin{array}{l}\text { Labour Force Participation } \\
\text { Rate (State-wise) Rural }\end{array}$ & 55.3per cent & 49.2per cent & MOSPI 2011-12 \\
\hline 4. & $\begin{array}{l}\text { Labour Force Participation } \\
\text { Rate (State-wise) Urban }\end{array}$ & 56.3per cent & 47.5per cent & MOSPI 2011-12 \\
\hline 5. & $\begin{array}{l}\text { Worker Population Ratio For } \\
\text { Female Aged } 15 \text { Years \& } \\
\text { Above According to Usual } \\
\text { Principal \& Subsidiary Status }\end{array}$ & 25.8per cent & 51.6 per cent & $\begin{array}{l}\text { E\&U Surveys of } \\
\text { Labour Bureau } \\
\text { 2015-16 }\end{array}$ \\
\hline
\end{tabular}

Table 1 shows the socio-economic indicators of women in India and Arunachal Pradesh. As per the table, Arunachal Pradesh is lagging behind the rest of India in the first four indicators, which is sex ratio, female literacy ratio, labour force participation rate (state-wise), rural and urban. However, the worker population ratio for females aged 15 years and above (according to usual principal and subsidiary status) is $51.6 \mathrm{per}$ cent in Arunachal Pradesh, which is a lot more than only 25.8 per cent in the rest of India. It is because an average woman in small tribal states like Mizoram, Nagaland, Chhattisgarh and Arunachal Pradesh is more likely to work than a woman living in urban areas like Delhi.

MSMEs are an excellent platform for women to strengthen their entrepreneurial capacity and explore new opportunities. Women in India are either registered as MSMEs or are engaged in informal businesses. However, only recently the Government of India has started collecting gender-wise information on ownership of MSMEs from 22 February 2017. As of 31 December 2019, 54 per cent and 15 per cent of MSMEs are owned by male and female, respectively. The remaining MSMEs had not updated their ownership by gender. ${ }^{1}$

It can be inferred from the above Table 2, that MSMEs registered under female's name is far less than male in rest of India as well as in Arunachal Pradesh. In percentage terms, the overall picture of females registered under MSME is slightly better in Arunachal Pradesh than in the rest of India. The total number of female registered under MSME is 23.02 per cent in Arunachal Pradesh and 21.43 per cent overall in India. 


\begin{tabular}{|c|c|c|c|}
\hline MSME & & India & Arunachal Pradesh \\
\hline \multirow{3}{*}{ Micro } & Male & $1,271,296$ & 171 \\
\hline & Female & 361,348 & 68 \\
\hline & Total & $1,632,644$ & 239 \\
\hline \multirow[t]{3}{*}{ Small } & Male & 185,267 & 110 \\
\hline & Female & 36959 & 17 \\
\hline & Total & 222,226 & 127 \\
\hline \multirow[t]{3}{*}{ Medium } & Male & 7,442 & 10 \\
\hline & Female & 1,064 & 2 \\
\hline & Total & 8,506 & 12 \\
\hline \multirow[t]{3}{*}{ Total } & Male & 1464005 & 291 \\
\hline & Female & 399,371 & 87 \\
\hline & Total & $1,863,376$ & 378 \\
\hline
\end{tabular}

\section{Primary Survey Findings in Arunachal Pradesh}

The age of 30 respondents ranged from 20 years to 48 years. The business venture initiatives are usually deeply rooted in tradition and culture which is seen in the various products like clothes, bags, cups and plates made by them. The educational profile of the respondents varied from primary school to post-graduate education. None of the respondents was illiterate. The entrepreneurs work primarily in environmentfriendly ventures like plant nursery, cane and furniture business.

\section{Types of Enterprise}

Figure 1 represents that 66.6 per cent of the enterprises are micro enterprise, earning a low income by engaging themselves as home-based producers. They started the micro-enterprise sector due to economic compulsions to support their family. Some of them also started them as their hobbies. Most of them operate from their own homes with less usage of technology. These enterprises are funded by family and informal loans from money lenders. Thirty per cent of them are small enterprises with better market exposure than those compared to microenterprises. The rest, 3.3 per cent are medium enterprise and have knowledge about import and export business to some extent. Overall, the level of awareness was found to be very poor among all the categories of respondents. However, the difference in awareness genderwise was seen to be higher among men than women entrepreneurs.

During the interview, entrepreneurs with microenterprise shared that they wanted to use new technology and were in need of more humanpower to expand their business, but many of them had no hope of getting a loan. Some of them had applied for a loan several times, but their documents were rejected each time. Then they borrowed capital from money lenders for which they had to pay very high interest. Therefore, even though they desired to grow their business, they could not do so due to these hurdles.

Table 3 shows that out of the 30 respondents, 20 are micro-entrepreneurs, 9 are small entrepreneurs, and 1 is a medium entrepreneur. 


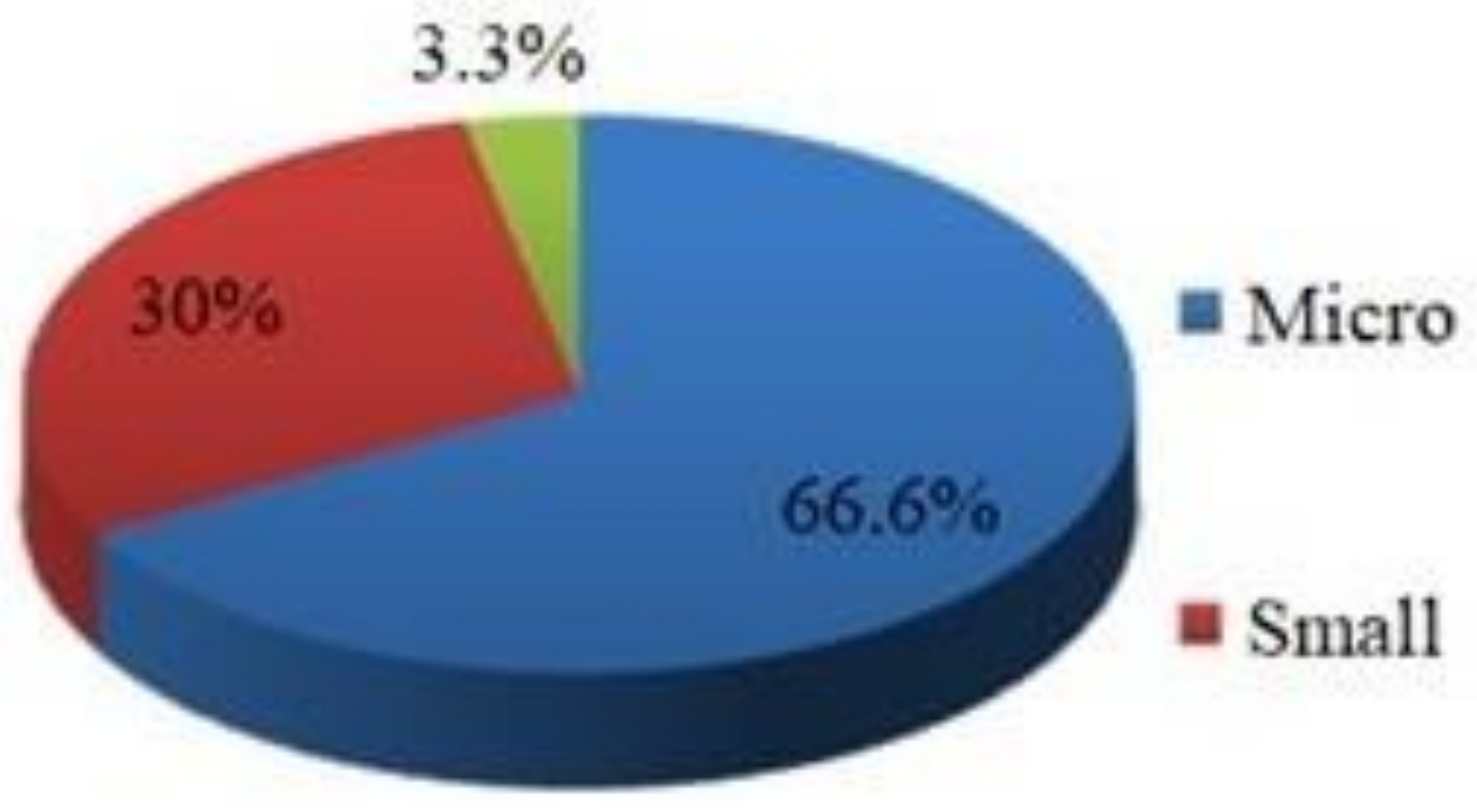

\section{= Medium}

Figure 1: Types of Enterprise

Source: Based on the Data of our Research

\begin{tabular}{|c|c|c|c|}
\hline \multicolumn{4}{|c|}{ Table 3: Types of Enterprise } \\
\hline $\begin{array}{c}\text { Total number } \\
\text { of } \\
\text { Respondents }\end{array}$ & Micro & Types of Enterprise & Small \\
\hline 30 & 20 & 9 & 1 \\
\hline Source: Based on the Data of our Research & & \\
\hline
\end{tabular}

\section{Knowledge about Import and Export}

According to the details furnished in Table 4, while the majority of them are familiar with the concept of import and export, 2 of the respondents were unaware of it.

\begin{tabular}{|c|c|c|}
\hline \multicolumn{2}{|c|}{$\begin{array}{c}\text { Table 4: Knowledge about Import and Export } \\
\begin{array}{c}\text { Tot } \\
\text { Respondents }\end{array}\end{array}$} & \multicolumn{2}{|c|}{$\begin{array}{c}\text { Knowledge about } \\
\text { Import and Export }\end{array}$} \\
\cline { 2 - 3 } & Yes & No \\
\hline 30 & 28 & 2 \\
\hline Source: Based on the Data of our Research & & \\
\hline
\end{tabular}

Also, a majority of them had not applied for a loan, while 10 of them had taken loans for their business. Twenty-one of the respondents were familiar with and used the internet for their business. However, a few of the respondents did not know how to use the internet in their business as highlighted in Table 5 . According to Figure 2, the use of internet in business by the 
respondents is 70 per cent, especially the use of knowledge and cannot operate smartphone. social media like Facebook, which gave them a They have never used the internet for their platform to advertise their products. Rest 30 per business. cent of the respondents do not have computer

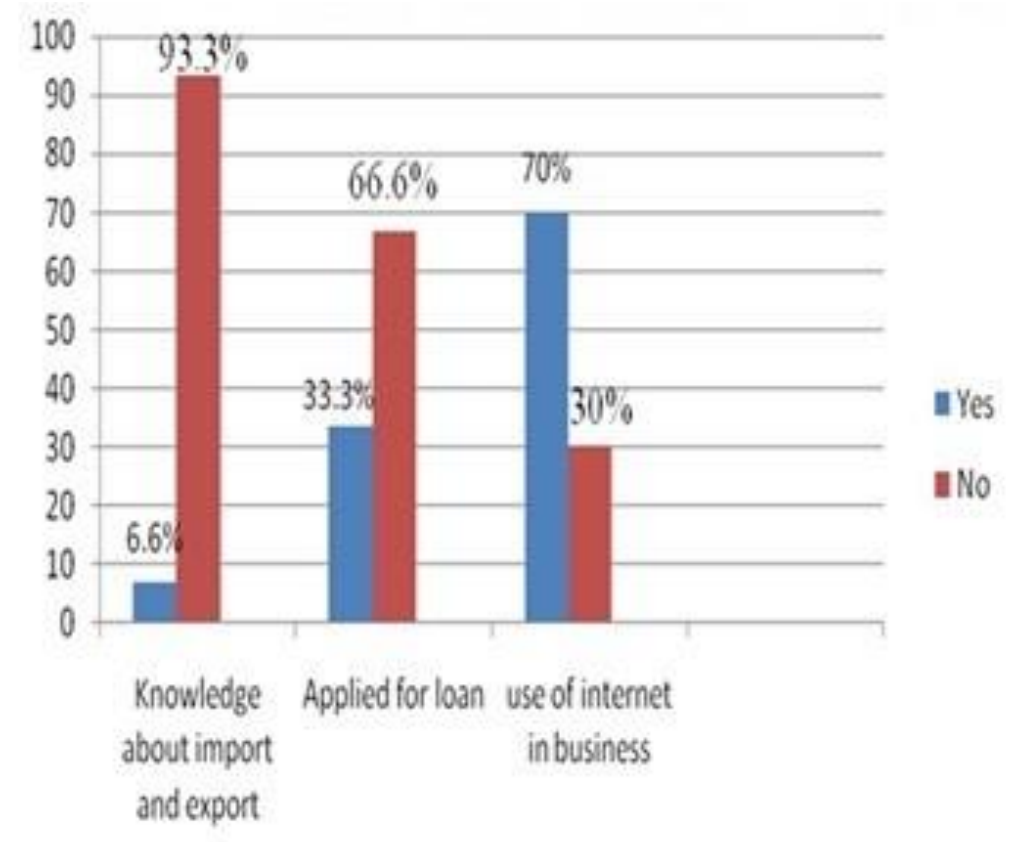

Figure 2: Knowledge about Import \& Export, Loan Application \& Use of the Internet in Business Source: Based on the Data of our Research

\begin{tabular}{l|l|l|l|l|}
\hline \multicolumn{4}{l}{ Table 5: Loan Application and Use of Internet in Business } \\
\hline $\begin{array}{l}\text { Total number } \\
\text { of }\end{array}$ & $\begin{array}{l}\text { Applied for Loan } \\
\text { Respondents }\end{array}$ & Yes & Yes & Use of the Internet in Business \\
\hline 30 & 10 & 21 & Yes & No \\
\hline
\end{tabular}

Source: Based on the Data of our Research

\section{Marital Status}

In Table 6, it is seen that most of the respondents (60 per cent) were married, (37 per cent) were unmarried, and ( 3 per cent) were divorced. It may be inferred that marriage is not seen as a hindrance to the business and livelihood method.

\begin{tabular}{|c|c|c|c|c|}
\hline \multicolumn{2}{|c|}{ Table 6: Marital Status of Respondents } \\
\hline \multirow{2}{*}{$\begin{array}{c}\text { Total Number of } \\
\text { Respondents }\end{array}$} & \multicolumn{3}{|c|}{ Marital Status } \\
\cline { 2 - 5 } & Married & Unmarried & Widow & Divorcee \\
\hline 30 & $\mathbf{1 8}$ & $\mathbf{1 1}$ & $\mathbf{0}$ & 1 \\
\hline \multicolumn{2}{|c|}{ Source: Based on the Data of our Research } \\
\hline
\end{tabular}




\section{Level of Education}

13 of the 30 respondents have either a graduate or a post-graduate qualification. Seven of them are high school graduates. One person has vocational training in the business set-up. No respondent had not received any formal education.

\section{Comparison between Men and Women}

Through the collected data, a few differences may be inferred between the men and the women respondents, as below:

- Motivational interest - 60 per cent of women ventured into entrepreneurship to become financially independent compared to 50 per cent of men.

- Another contrast was seen that while 10 per cent of women were working to finance their children's education, none ( 0 per cent) of men respondents were doing it.

- Household Activity - most of the women (80 per cent) were involved in a household activity like cooking, childcare etc., while none of the men was involved in the same.

- Awareness Level - No significant correlation could be drawn in the level of awareness between male and female respondents to draw inferences. For example, there were only two (02) men out of ten (10), that is, 20 per cent of the total male respondents who conveyed about being aware of the land cost, whereas there were seven (07) women out of twenty (20) female respondents that is, 35 per cent who informed being aware of the land cost. While there was only one male respondent who was not mindful of the building cost, 90 per cent of the male respondents were aware of building cost compared to 75 per cent of women who reportedly were aware of the same. Hence, there was no significant correlation between the level of awareness and gender dimensions in the state. Other factors like gender roles and other bottlenecks were common as in other parts of the country.
Arunachal Pradesh is rich in resources like bamboo, also termed as 'Green Gold', and there is a high demand for handicrafts made of it. Bamboo is not only known for handicrafts, but the pickles made from bamboo shoots are also in high demand. Mrs Occa, the proprietor of SpiceZiro from Ziro, mentioned during an interview that while participating in an exhibition, her product was appreciated by the countries like Thailand, China and South Korea due to similarity in food culture. She got an offer to sell her products in South Korea, but she could not meet the demand due to low production.

\section{Domestic and International Market Access: Awareness, Resources, and Concerns}

\section{Domestic Market: Access and Challenges}

Many factors are directly or indirectly related to entrepreneurship, like no direct contact with customer and whole seller, complex taxregime,etc. Lack of infrastructure facilities like warehouses, cold storage facilities, transportation, etc. are vital factors for economic activity.

As depicted in Figure 3, multiple bottlenecks related to infrastructure, institutional and policyrelated concerns were reported by the respondents. Higher transport cost and no direct link with customers was reported by 21.05 per cent of respondents. 21.05 per cent of respondents opined that they have to face loss sometimes due to higher transportation charges. Transportation provides essential service of linkage to producer and consumer-like moving goods from locations where they are sourced to market. Transportation is an essential activity in the logistic function, supporting the economic utilities of place and time (Goldsby, Iyengar \& Rao, 2014). Place utility means that consumers have product available where they demand, and time utility means consumers have access to it. Challenges differ from the type of enterprise and person to person. 21.05 per cent of respondent think that direct connection with the customer would help them increase their profit. During the interviews, some innovative entrepreneurs stated that they face loss in their business due to imitation. Modern and traditional fusion dress is in trend nowadays, and 
their product was in demand in Arunachal Pradesh. Women of Arunachal Pradesh have skill in weaving traditional dresses, and now there are plenty of entrepreneurs who are making the same dresses and even selling at low price.

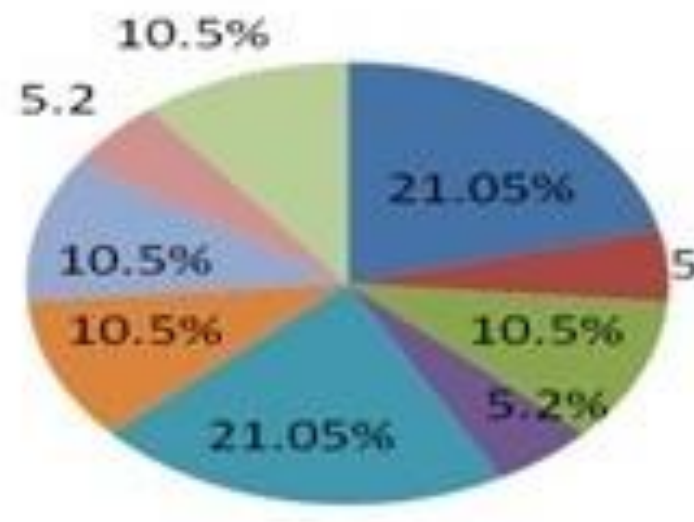

= No direct link with eustomer

$=$ No direct link with retailer

= No direct aceess to whole seller

= Transport infrastructure inefficient

= High transport cost

m High tax

Complex tax regime

= Lack of ware house facility

= Lack of cold storage and eold chain

Figure 3: Challenges in Accessing Domestic Market Source: Based on the Data of our Research

\section{Awareness of International Market}

All except one enterprise, namely Ajin Ana Society that works with bamboo products, cane and furniture, expressed a lack of awareness about procedure, challenges or even supporting partners of whose exported raw materials they use for the manufacturing of their products and otherwise.

As depicted in Figure 4, it is observed that there is a lack of awareness about the regulatory institutions, promotional institutions, credit institutions and representative institutions. According to data (refer to Figure 2), only 6.6 per cent of entrepreneurs interviewed for this study were aware of the export business, and the rest of the respondents did not have any knowledge about it. Lack of awareness amongst women about financial assistance like incentives, loans, and schemes by the institutions in the financial sector is one of the significant challenges. Despite financial policies and programmes for women entrepreneurs, financial support has reached only a few women entrepreneurs. Another reason why women are reluctant to participate in the export business because they do not have much information on trade procedures and rules and regulations related to international trade. Women entrepreneurs are not aware of the implementation and benefits of 'Bangladesh, Bhutan, India, Nepal Motor Vehicles' Agreement of 2015, which aims to facilitate cargo movement across the borders more easily and swiftly, thereby, reducing the trade transaction cost, encouraging economic opportunities in border areas and benefitting startups and MSMEs. 


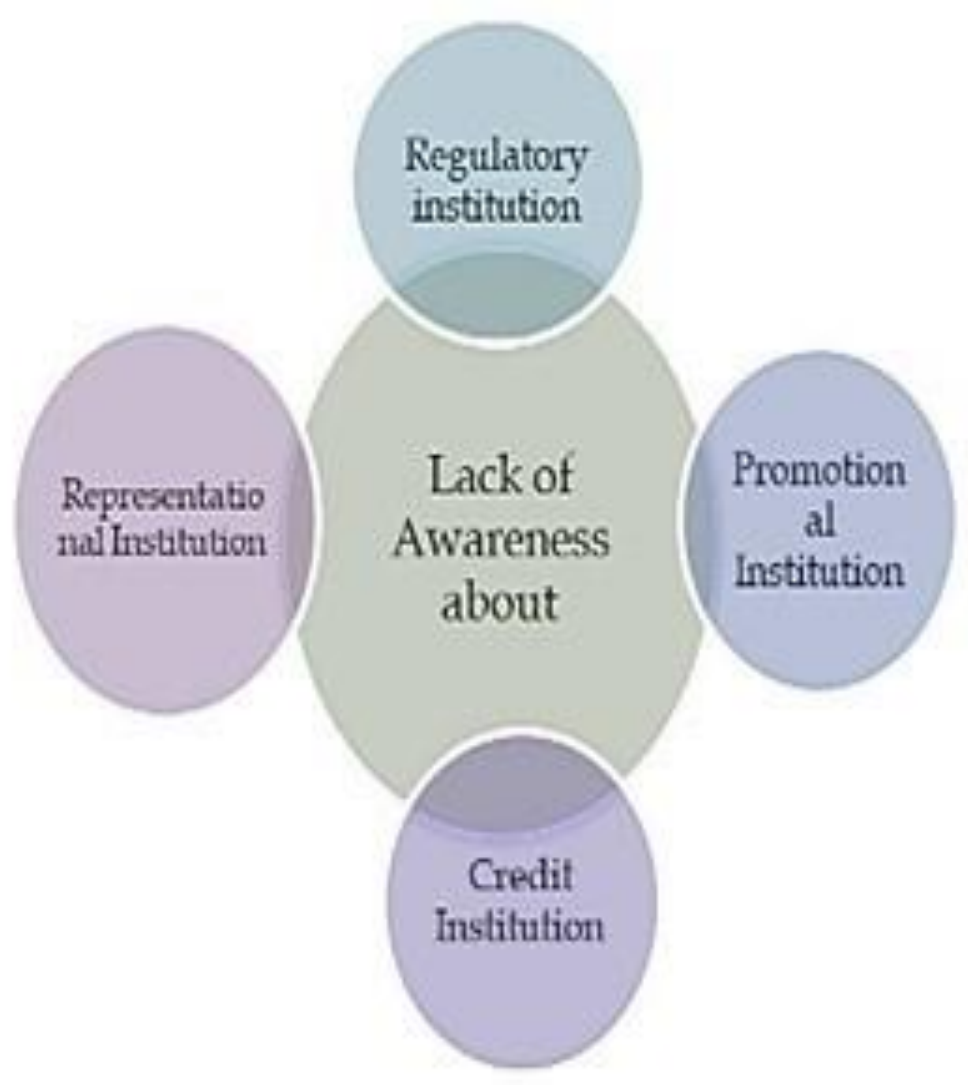

Figure 4: Venn Diagram on Lack of Awareness

Source: Based on the Data of our Research

\section{Key Findings}

Given the small sample size, it is impossible to draw any broad generalisations on the basis of this study. However, the rich and in-depth data from case studies provide information about both male and female entrepreneurs in the state, which have been summarised here to put forth implications for future research and practice:

\section{Awareness on Importing Countries of Raw Materials}

The majority of the enterprises (20 of the female-owned; 7 of the male-owned) used imported raw materials for their products. However, they were not aware of the countries they imported their raw materials from, and the majority of them also sold their products throughout the year. Except for one enterprise that imported flowers, others were not aware of the type of items they imported from abroad.

\section{Domestic Market Access, Transport and Logistics}

The majority of the enterprises were in direct business with the customers. While 3 of the enterprises worked with the retailer, 2 of them worked with wholesalers. The retailers are relatively close (in terms of distance) to the enterprises. They are situated on an average of $2.1 \mathrm{~km}$ from their location. The majority (16) determined the cost of the products in the region by negotiating with buyers, while 13 of the enterprise fix the price based on the cost of the production. A few of the products' price depends on buyers' will or after discussion with other sellers. The entrepreneurs faced different kinds of difficulty in accessing the domestic markets, such as: not having a direct link with customers, high transport cost owing to the remote location, rugged geographical terrain, underdeveloped social infrastructure, the abysmal status of public transport, the total 
absence of advanced means like no airport and poor road connectivity in the state.

\section{International Market Access}

Ajin Ana Society that works with bamboo, cane and furniture products was the sole enterprise that had international market access. Hence, 29 out of 30 , that is, a highly significant percentage of 96.7 per cent entrepreneurs, had no international market access in the state.

\section{Awareness about Trade Procedures and Formalities}

As highlighted earlier, except one, all the other respondents of both the gender (29 out of 30) reported to be unaware of the various factors related to international trade. The only enterprise namely Ajin Ana Society, that works with bamboo products, cane and furniture, expressed awareness about International Trade Procedure and Formalities.

\section{Exception/Subsidy related to International Market}

Except for Ajin Ana Society, the rest of the entrepreneurs, reportedly, were not aware of the subsidy, as they did not have International market access.

\section{International Market Access Challenges Related to Transport}

While only one enterprise exported their products directly, the others did not. Ajin Ana Society reportedly did not find any difficulty regarding the transport services and even complied with Customs House Agent.

\section{International Market Access Challenges Related to Trade Logistics and Standards}

When asked if the company faced any problem in transporting goods until the border, only 1 out of the 30 enterprises could answer this question while the rest reported having no knowledge. All the 30 enterprises deal with the customer directly and do not supply their products to other stores, which should be why most of them seem to be unaware of it.

\section{International Market Access Challenges Related to Customs and Border}

The enterprises in the sample being local, reported, not to have supplied to different countries, which explains the surprisingly high percentage ( 96.6 per cent) being unaware of the different challenges in accessing international markets related to customs and borders.

\section{Grievance Redressal}

Only 5 out of 30 enterprises reported having faced grievances during the course of their business. Some of which is extortion by local militant/ anti-social groups, loans rejected by banks because of the lack of required documents. The small number of grievances seem very unrealistic considering the many risks in entrepreneurship. The only plausible reason seems to be subjects' reluctance or trust issues in responding to a largely unknown researcher.

\section{Level of Digital Inclusion}

Most of the enterprises have a fair knowledge of modern technologies. The use of social media as a platform to advertise their product was reported to be getting popular increasingly. But only a handful of them reported selling their products online. More than one enterprise had listed the absence of reliable courier service as the reason for not selling online while other reasons stated were: weak internet, less knowledge, and customer's preference to purchase directly from the store.

\section{Level of Financial Inclusion}

Seventy-six per cent of the entrepreneurs possess separate bank accounts for their business, which is due to the efficiency and security of the bank. The most popular means of transaction among the above 76 per cent, was a debit card, and the least was internet banking and through cheques. Taking loans is one of the unavoidable circumstances in the business of trade unless the person belongs to an economically well-off family. Among the 30 traders, 62 per cent of the respondents reported not having any existing loans, which seems unlikely. This might be because many traders in Arunachal Pradesh still rely on borrowing money 
from their social circle (or even contributions from well-wishers). Therefore, no existing loans were reported by a significantly high proportion (62 per cent) of respondents.

\section{Social Factors}

The most striking difference reported between male and female respondents was that none of the male subjects had any role in a household activity like cooking, child caring, while 80 per cent of the women subjects had to spend around 2.6 hours per day doing the same. This shows that, like in most Indian states, in Arunachal Pradesh, the society believes that it is a woman's responsibility to take care of the household, irrespective of their jobs. While men, with or without jobs, play no role in managing the house.

\section{Conclusion and Recommendations}

In Arunachal Pradesh, the market is mainly controlled by women, yet the participation of women in small and medium enterprise is less in number. Women entrepreneurs are influenced by both push and pull factors. Pull factors include aspirations for autonomy and independence, personal satisfaction and achievement, a search for the challenge, challenging stereotypes and gap in the market. Push factors include dissatisfaction with the labour market, need for higher income, unemployment, desire for a better life, higher earnings, financial incentive and motivation from governmental schemes for assistance, the attraction of high-profit margins and many more (Shah, 2013). The status of women entrepreneurs in Arunachal Pradesh has been changing due to globalisation, industrialisation, and internet use. Women entrepreneurship is challenging as availing finance, managing an enterprise and balancing many responsibilities are significant hurdles faced by women. Other external factors include gender discrimination, inaccessibility to information, lack of training opportunities and infrastructure. Some internal factors are risk aversion by women, lack of self-esteem and selfconfidence, lack of vision that hinder women entrepreneurship (Sahoo, 2020). Lack of information about the availability of raw material, access to finance and Governmental schemes and facilities and other existing or upcoming opportunities often acts as hurdles for women entrepreneurs.

Entrepreneurship, being a composite kind of activity, has been linked up with social, economic, and environmental factors that affect an entrepreneur's attitudes, motivations, and development. Some of these factors could be age, marital status, religion, caste, economic status, education, type of family and culture. The demographic background, socio-cultural factors, motivation, and purpose of the business have a positive effect on promoting women entrepreneurship and improving their performance.

A balanced approach to nurturing entrepreneurship will definitely result in a positive impact on the economy and society. Entrepreneurship puts new business ideas into practice. In doing so, it creates jobs that facilitate personal development. With their innovative ideas, entrepreneurs can tackle social problems too. On the whole, the role of entrepreneurship in economic development of a country can best be put as "an economy is the effect for which entrepreneurship is the cause".

Based on the findings of the study, the following recommendations are drawn out:

\section{Infrastructure Related Concerns}

Infrastructure is a broad term for the physical structures and facilities like roads, power supply, water supply, technology etc. used to generate goods and services. Due to difficult terrain, entrepreneurs face challenges related to transportation, unavailability of cold storage and warehouses etc. There is a need to set up facilities such as food testing units, cold storage and warehouses etc.

\section{Road Connectivity}

The difficult geographical terrain of Arunachal Pradesh and poor quality of roads more often than not lead to untimely delivery and an increase in manufacturing cost. This subsequently increases the end price, which sometimes becomes the reason for the business venture's failure. It often results in increased 
costs and low competitiveness in the market. The government could intervene with subsidised transportation facilities for women in the region to encourage their participation.

\section{Water and Power Supply}

Arunachal Pradesh is home to many tributaries of the River Brahmaputra which can perhaps be harnessed to generate the uninterrupted supply of energy. But unfortunately, it does not get a quality supply of energy which delays and halts the production process. The above-listed infrastructure facilities and other facilities like technology, cold storage, and warehouses are all expensive investment but significant inputs for the start of an enterprise. This is the area where most entrepreneurship ventures tend to fail.

\section{Awareness Generation}

Government policies are in place to help startups, but most of the entrepreneurs remain unaware of them because of poor enabling environment, lack of advertisement, and insufficient research and innovation in the state. The policies and programmes for the entrepreneurs do not reach the targeted stakeholders.

If the entrepreneurs are informed, they would be expanding their business internationally, at least to the nearest neighbouring border nations, perhaps, through the Act East Policy, which enables trade exchanges and better infrastructure development for connectivity in the region (Pulla et al., 2020). Hence, an institutional and regular arrangement for strengthening the enabling environment, that is, capacity building of entrepreneurs, needs to be established in the prevailing circumstances in the state.

\section{Institutional and Policy Related Bottlenecks}

Concluding from the various responses gathered from the entrepreneurs, it can be said that there is a serious lacuna in the decentralisation of the implementation of the policies of the government. In the context of Arunachal Pradesh, there is localisation of the produced goods by the enterprises. The entrepreneurs should have been encouraged and facilitated to profit out of the strategic location of Arunachal Pradesh to the nearby nations.

\section{Training and Capacity Building}

The government needs to institutionalise capacity building and enable conditions viz. institutionalising skill training and awareness of existing promotional measures imparted to the budding women entrepreneurs. However, such training is always seen or heard to be conducted in India's already well-to-do cities. The government could shift their attention to the border states of India by imparting the required knowledge so that the nation may benefit from the cross-border trade.

It is seen that even when training is imparted, the resource person is usually not an expert but rather a new person herself/himself in the field. At times, the training is gender-stereotyped where women are trained for beauty parlours, cloth, edible business, and men for a wider field. This observation resonates with that of Das (2003), who stated that women continue to be in trades that are considered the domain of women. The responsibility in this regard can be shared by Union as well as Federal Government proportionately.

In the 2014 and 2019 legislative assembly elections, only 2 and 3 women candidates won, respectively, which shows the poor representation of women in the state's legislative assembly. Therefore, a need for enabling environment is also established so that concerns of women entrepreneurs may be highlighted and addressed adequately.

\section{Financial Institutions}

The banks and other financial institutions are seen to trust men more than women entrepreneurs. This prejudice needs to be addressed, and better schemes should also be given to women entrepreneurs. The family and society should also support the women in their venture. Rather than looking down on their startup, they should try purchasing locally produced goods instead of going for the already established multi-national company (MNC) and their products. 


\section{References}

Beneria, L. (2003). Gender, Development, and Globalisation: Economics as if All People Matters. Routledge.

Boserup, E. (1970). Women's Role in Economic Development. George Allen and Unwin.

Comité québécois Femmes et développement (CQFD) of Association québécoise des organismes de coopérationinternationale (AQOCI). (2004). Training Kit: Gender and Development. https://www.aqoci.qc.ca/wpcontent/uploads/2011/12/pdf_guides_200403_trainingkitged_2_.pdf

Census. (2011).

https://censusindia.gov.in/2011-

common/censusdata2011.html

Das, M.B. (2003). The Other Side of Self-

Employment: Household Entreprises in India. World Bank Social Protection Discussion Paper No. 318, Washington, DC: World Bank.

Goldsby, T.J., lyengar, D. \& Rao, S. (2014). The Critical Role of Transportation in Business and the Economy. In Definitive Guide to Transportation: The Principles, Strategies, and Decisions for the Effective Flow of Goods and Services.

https://www.informit.com/articles/article.aspx ? $\mathrm{p}=2171313$.

Jackson, C. \& Pearson, R. eds. (1998). Feminist Visions of Development. London: Routledge.

Jaquette, J.S. \& Staudt, K. (2006). Women and Gender Equity in Development Theory and Practice. Duke University Press.

Kabeer, N. (1994). Reversed Realities: Gender Hierarchies in Development Thought. Verso.

Mlambo, C. \&Kapingura, F. (2019). Factors influencing women political participation: The case of the SADC region. Cogent Social Sciences, 5 (1). DOI: $10.1080 / 23311886.2019 .1681048$

Mohammed, A. \& Ayah, A. (2019). Importance of Entrepreneurship in Economic Development. Entrepreneurship and Regional Development.
Muyoyeta, L. (2007). Women, Gender and Development .80:20 Educating and Acting for a Better World.

Onyejekwe, C.J. (2004). Economic globalisation and the free market ethos: A gender perspective, Nebula 1(1), 26-31.

Pulla Ventak, Sarmah Gunindra Nath and Nath Hiranya K. (2020). Look/Act East Policy and North East India: Issues, Concerns and Opportunities. In Pulla, Venkat, Bhattacharyya Rituparna \& Bhatt Sanjay (eds.). Discrimination, Challenge and Response: People of North East India. Palgrave Macmillan, 161-175. https://doi.org/10.1007/978-3-030-46251-2_9 Rathgeber E.M. (1990). WID,WAD, GAD: Trends in Research and Practice, The Journal of Developing Areas, 24(4), 489-502.

Sahoo, C. (2020). Women Entrepreneurship in India: An Insight into Problems, Prospects and Development. International Journal of Engineering Research and Technology. 9(9). http://dx.doi.org/10.17577/IJERTV9IS090224

Shah, H. (2013). Creating An Enabling Environment for Women's Entrepreneurship, UNESCAP.

https://www.unescap.org/sites/default/files/ES CAP-SSWA-Development-Paper_1304_1.pdf

Taneja, N., Joshi, S., Prakash, S., Bimal, S. (2018). Trade Facilitation Measures to Enhance Participation of Women in Cross-border Trade in BBIN. http://hdl.handle.net/11540/8249.

Tinker, I. (1990). Persistent Inequalities: Women and World Development. Oxford University Press

Trade Winds of Change - Women Entrepreneurs on the Rise in South Asia, 2016.

http://www.asiapacific.undp.org/content/rbap/en/home/library /sustainable-development/trade-winds-ofchange.html.

Zwart, G. (1992). From Women in Development to Gender and Development, More than a Change in Terminology?, Empowering Women for Gender Equity. 14, 16-21 


\section{Conflict of Interest}

We declare that we have no conflict of interest

\section{Acknowledgements}

The authors would like to acknowledge contributions from all the primary and secondary sources whose data and writings have significantly benefitted the article in formulating lines of argument and drawing inferences for analysis.

\section{Author Contribution Statement}

Dr. Kaushalendra Pratap Singh has contributed to collecting data, conceptualisation and designing the manuscript, writing the first draft, methodology, documenting the second draft.

Dr. Saumya has contributed to developing the first draft, incorporating new ideas and relevant resources, final reviewing and re-writing the final draft, cross-checking for references.

Ms. Chetna K. Rathore has contributed to the initial reviewing the manuscript. 